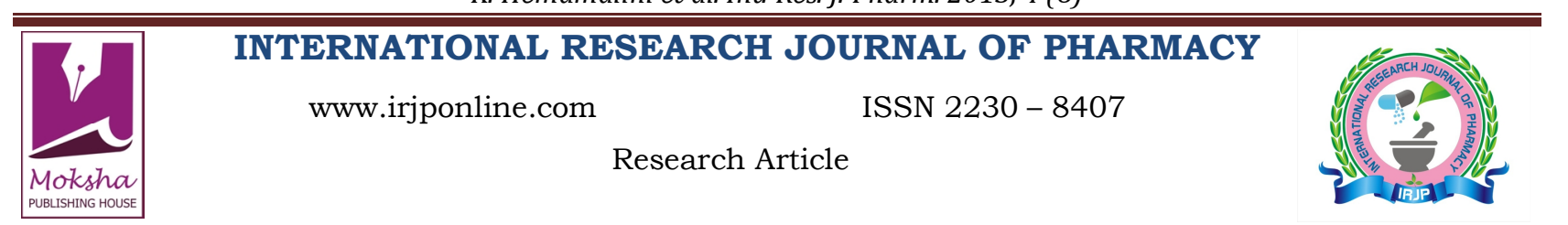

\title{
EVALUATION OF PHYTOCHEMICAL AND PHARMACOLOGICAL ACTIVITY OF METHANOLIC EXTRACT OF SOLANUM PUBESCENS \\ K. Hemamalini ${ }^{1 *}$ and Anurag bhargav ${ }^{2}$ \\ ${ }^{1}$ Research scholar, Institute of Pharmaceutical sciences and Research Centre, Bhagwant University, Ajmer, Rajasthan, India \\ ${ }^{2}$ Principal, Devi Lal College of Pharmacy Bhagwangarh, Buria Road, Jagadhri, Haryana, India \\ *Corresponding Author Email: rkhemamalini@gmail.com
}

Article Received on: 13/06/13 Revised on: 08/07/13 Approved for publication: 11/08/13

DOI: 10.7897/2230-8407.04825

IRJP is an official publication of Moksha Publishing House. Website: www.mokshaph.com

(C) All rights reserved.

\begin{abstract}
Traditional medicine has a long history of serving people all over the world. In recent years, the use of traditional medicine information in cancer research received considerable interest. Solanum pubescens has been used in traditional and folklore medicine for the treatment of cancer. The aim of the present study was to evaluate the effect of methanol extract of the leaves against intraperitoneally injected Dalton's Ascitic Lymphoma (DAL) cell line in swiss albino mice. DAL cells were injected intraperitoneally $\left(1 \times 10^{6}\right.$ cells $/ \mathrm{ml} /$ mouse) to the mice. The MESP at a dose of $100 \mathrm{mg} / \mathrm{kg}$ and $200 \mathrm{mg} / \mathrm{kg}$ body weight were administered orally for 14 consecutive days to the tumor bearing group of animals. Derived parameters, haematological parameters, serum enzyme and lipid parameters were measured and compared to the cancer control group. 5- Flurouracil $(20 \mathrm{mg} / \mathrm{kg})$ was used as a standard. Both the dose of MESP decreased average increase in body weight, reduced the packed cell volume, viable tumor cell count and increased the life span of DAL treated mice and brought back the haematological parameters, serum enzyme and lipid profile near to normal values. All the values were found to be statistically significant with cancer control group at $\mathrm{P}<0.01$. These observations are suggestive of the protective effect of extracts in Dalton's Ascitic Lymphoma (DAL). All these findings enable to conclude that MESP at $200 \mathrm{mg} / \mathrm{kg}$ dose possess a protective effect against DAL.
\end{abstract}

Keywords: Solanum pubescens, antitumor activity, Haematological and biochemical parameters, Dalton's ascetic lymphoma, 5-flurouracil.

\section{INTRODUCTION}

Cancer is expected to claim 9 million deaths worldwide by the year 2015. Cancer is an abnormal type of tissue in which the cells exhibit an uncontrolled division, relatively in an autonomous fashion, leading to a progressive increase in the number of cell dividing cell ${ }^{1}$. Lymphoma is a disease of lymphocytes (a type of white blood cell involved in immune responses and the lymphatic system, which includes in the Spleen, thymus and liver as well as other lymphatic tissues. Dalton's ascites lymphoma is transplantable, poorly differentiated malignant tumor which appeared originally as lymphocytes in a mouse. It grows in both solid and ascetic form $^{2}$. Cancer is one of the ailments which cannot be completely subdued by chemotherapy. The chemotherapeutic agents though effective against various types of tumour are not totally free from side effects ${ }^{3}$. Traditional medicine has aroused renewed interest as worldwide efforts continue the search for novel compounds that exhibit potent and selective anticancer properties. This fostered our attempts to evaluate some products against cancer, as they are less likely to cause serious side effects. Many Indian plants like black pepper, asafoetida, pippali and garlic are quoted to be useful indifferent types of cancer ${ }^{4,5}$. One such plant is Solanum pubescens belong to the family Solanaceae commonly called as "pajarito" which is a shrub. It exhibits gastroprotective activity $^{6}$, antinociceptive activity, anthelmintic activity ${ }^{7}$, anti lice activity $^{8}$, Flavonol 3-O-Methyl Ethers ${ }^{9}$ and Solanopubamine $^{10}$, a steroidal alkaloid are isolated from Solanum pubescens.

\section{MATERIALS AND METHODS}

\section{Collection and Authentication of Plant}

The leaves of Solanum pubescens were collected from surroundings of Seshachalam hill ranges of Triumala, Tripathi, Andhra Pradesh, India during the month of August. The plant material was taxonomically identified and authenticated by Dr. Madhava Chetty, Associate professor,
Department of Botany, S.V. University, Tripathi ${ }^{11}$ and a copy has been preserved for the future reference at the herbarium of the institute TRR College of Pharmacy. The leaves of Solanum pubescens were dried in the shade, milled into coarse powder by a mechanical grinder and stored in air tight closed container for further use.

\section{Preparation of the Plant Extract}

The air dried coarse powder of the leaves of Solanum pubescens was extracted with methanol using soxhlet's apparatus. The powdered material $(2 \mathrm{~kg})$ was defatted with petroleum ether $\left(60-80^{\circ} \mathrm{C}\right)$ in a soxhlet extraction apparatus and marc was extracted with methanol $(1000 \mathrm{~mL})$ over night, at room temperature with constant stirring. The extract was filtered and the filtrate was concentrated at $30^{\circ} \mathrm{C}$ under reduced pressure in a rotary evaporator. The crude extract was dissolved in distilled water to required concentrations and used for the experiments. The crude extracts were subjected to qualitative tests for the identification of various active constituents.

\section{Phytochemical Screening}

Phytochemical screenings were performed using standard procedures as follows ${ }^{12,13}$.

\section{Test for Reducing Sugars (Fehling's test)}

The aqueous ethanol extract $(0.5 \mathrm{~g}$ in $5 \mathrm{ml}$ of water $)$ of individual plants was added to boiling Fehling's solution (A and $\mathrm{B}$ ) in a test tube. The solution was observed for a colour reaction.

\section{Test for Anthraquinones}

The individual plant extract $(0.5 \mathrm{~g})$ was boiled with $10 \mathrm{ml}$ of sulphuric acid $\left(\mathrm{H}_{2} \mathrm{SO}_{4}\right)$ and filtered while hot. The filtrate was shaken with $5 \mathrm{ml}$ of chloroform. The chloroform layer was pipette into another test tube and $1 \mathrm{ml}$ of dilute ammonia 
was added. The resulting solution was observed for colour changes.

\section{Test for Terpenoids (Salkowski test)}

To $0.5 \mathrm{~g}$ each of the individual extract was added $2 \mathrm{ml}$ of chloroform. Concentrated $\mathrm{H}_{2} \mathrm{SO}_{4}(3 \mathrm{ml})$ was carefully added to form a layer. A reddish brown coloration was confirmed for the presence of terpenoids.

\section{Test for Flavonoids}

A portion of the individual plant extract $(0.5 \mathrm{~g})$ was heated with $10 \mathrm{ml}$ of ethyl acetate over a steam bath for 3 minutes. The mixture was filtered and $4 \mathrm{ml}$ of the filtrate was shaken with $1 \mathrm{ml}$ of dilute ammonia solution. A yellow coloration indicates the presence of flavonoids.

\section{Test for Saponins}

To $0.5 \mathrm{~g}$ of each plant extract was added $5 \mathrm{ml}$ of distilled water in a test tube. The solution was shaken vigorously and observed for a stable persistent froth. The frothing was mixed with 3 drops of olive oil and shaken vigorously after which it was observed for the formation of an emulsion.

\section{Test for Tannins}

About $0.5 \mathrm{~g}$ of the individual extract was boiledin $10 \mathrm{ml}$ of water in a test tube and then filtered. A few drops of $0.1 \%$ ferric chloride $\left(\mathrm{FeCl}_{3}\right)$ was added and observed for brownish green or a blue-black coloration

\section{Test for Alkaloids}

$0.5 \mathrm{~g}$ of each extract was diluted to $10 \mathrm{ml}$ with acid alcohol, boiled and filtered. To $5 \mathrm{ml}$ of the filtrate was added $2 \mathrm{ml}$ of dilute ammonia. $5 \mathrm{ml}$ of chloroform was added and shaken gently to extract the alkaloidal base. The chloroform layer was extracted with $10 \mathrm{ml}$ of acetic acid. This was divided into two portions. Mayer's reagent was added to one portion and Draggendorff's reagent to the other. The formation of a cream (with Mayer's reagent) or reddish brown precipitate (with Draggendorff's reagent) was regarded as positive for the presence of alkaloids.

\section{Test for Cardiac Glycosides (Keller-Killiani test)}

To $0.5 \mathrm{~g}$ of individual plant extract diluted to $5 \mathrm{ml}$ in water was added $2 \mathrm{ml}$ of glacial acetic acid containing one drop of ferric chloride solution. This was under layer with $1 \mathrm{ml}$ of concentrated $\mathrm{H}_{2} \mathrm{SO}_{4}$. A brown ring at the interface indicated the presence of a deoxysugar characteristic of cardenolides. A violet ring may appear below the brown ring, while in the acetic acid layer a greenish ring may form just above the brown ring and gradually spread throughout this layer.

\section{Cell line}

The (DAL) Dalton's Lymphoma Ascites cells were obtained from Amala Cancer Research Center, Thrissur, Kerela, India. The DAL cells were maintained in vivo in swiss albino mice by intraperitoneal inoculations of $1 \times 10^{6}$ cells / mouse. While transforming the tumor cells to the grouped animal the DAL cells were aspirated from peritoneal cavity of the mice using saline. The cell count was done and further dilutions were made, so that total cells should be $1 \times 10^{6}$ cells / mouse. This volume was given intraperitoneally and the tumor was allowed to grow in the mice for a minimum of seven days before starting the study.

\section{Experimental Animals}

Swiss albino mice weighing between 18-22 g of either sex were procured from the standard animal house, National institute of nutrition, Hyderabad, India; they were maintained under standard environmental conditions and were fed with standard laboratory diet and water ad libitum. They were maintained in a controlled environment (temp $25 \pm 2^{\circ} \mathrm{C}$ ) and a relative humidity of $45-55 \%$ under $12 \mathrm{~h}$ light / dark cycles. The experimental protocol was approved by the Institutional Animal Ethical Committee (IAEC) (1447/PO/a/11/ CPCSEA). CPCSEA guidelines were adhered during the maintenance and experiment.

\section{Treatment Protocol}

Tumor was induced by injecting $0.2 \mathrm{~mL}$ of $1 \times 10^{6} \mathrm{~mL}-1$ of DAL into peritoneal cavity of mice. The animals were divided into 5 groups $(\mathrm{N}=6)$. All the groups were injected with DAL cells $\left(1 \times 10^{6}\right.$ cells / mouse) intraperitoneally except normal group. This was taken as day 0 . The treatment was given as follows:

Group I : Control $(0.9 \% \mathrm{w} / \mathrm{v}$ of $0.2 \mathrm{ml}$ of saline, i.p., ) from day 1 to 14 ,

Group II: Tumor control (DAL)

Group III: Treated with MESP at a dose of $100 \mathrm{mg} / \mathrm{kg}$ body weight,

Group IV: Treated with MESP at a dose of $200 \mathrm{mg} / \mathrm{kg}$ body weight,

Group V: Positive control, treated with 5 Flurouracil $20 \mathrm{mg} /$ $\mathrm{kg}$ body weight intraperitoneally.

For the study against DAL cell lines, MESP dissolved in $2 \mathrm{ml}$ sterile water was administered orally for 14 days. On $15^{\text {th }}$ day, after the last dose and $18 \mathrm{~h}$ fasting 6 mice from each group were sacrificed for the study of antitumor activity, Hematological and antioxidant enzyme estimation and rest of the animals of each group were kept to check the mean survival time (MST) and percentage increase in lifespan (\%ILS) of the tumor bearing mice.

\section{Tumor Growth Response}

Antitumor effect of MESP was assessed by observation of changes with respect to body weight, ascetic's tumor volume, packed cell volume, viable and non viable tumor cell count. MST and \%ILS were also calculated. Transplantable tumor was carefully collected with the help of a sterile $3 \mathrm{~mL}$ syringe, measured the tumor volume and the ascetic fluid was withdrawn in a graduated centrifuge tube, viable and non viable cell count of ascetic cell were stained by the tryphan blue $(0.4 \%)$ in normal saline dye exclusion test and count was determined in Neubauer counting chamber. The effect of METR on tumor growth was monitored daily by recording the mortality and \%ILS was calculated using following formula

$$
\% \mathrm{ILS}=\frac{\begin{array}{c}
\text { (Mean survival of treated group }- \text { Mean survival of control } \\
\text { group) }
\end{array}}{\text { Mean survival of control group. }}
$$

\section{Collection of Blood and Parameters Analyzed}

In this study, drug treatment was given $24 \mathrm{~h}$ after inoculation, once daily for 14 days. After the last dose, all mice from all the groups were sacrificed, the blood was withdrawn from each mouse by retro orbital plexus method and the following parameters like haematological and biochemical parameters were analyzed. 


\section{Hematological Studies}

Blood was collected from the Retro orbital plexus and drawn into $\mathrm{RBC}$ or WBC pipettes, diluted and counted in a Neubauer counting chamber Sahli's Hemoglobin meter determined of hemoglobin concentration. Hemoglobin content $^{14} \mathrm{RBC}, \mathrm{WBC}^{15}$ counts were estimated from the peripheral blood of nomal, DAL control and extract treated groups.

\section{Histopathological Analysis}

A portion of the liver was cut into 2-3 pieces of approximately $3.8 \times 3.0 \times 1.5 \mathrm{~cm}$ and fixed in $10 \%$ formaldehyde solution. After embedding in paraffin wax, thin sections of liver tissue were sliced and stained with hematoxylin-eosin. The thin sections of liver were made into permanent slides and examined under high resolution microscope with photographic facility and photomicrographs were taken.

\section{Statistical Analysis}

Total variation present in set of data was performed by using one way Analysis of variance (ANOVA) followed by Dunnett's test and the results are expressed as Mean \pm SEM.

Table 1: Effect of Methanolic Extract of Solanum pubescens on Tumour Volume, Viable and Nonviable Tumour Cell Count of DAL Bearing Mice

\begin{tabular}{|c|c|c|c|c|}
\hline Parameters & $\begin{array}{c}\text { DAL Control }\left(1 \times 10^{6}\right. \\
\text { cells / mouse / ml })\end{array}$ & $\begin{array}{c}\text { MESP + DAL } \\
(200 \mathrm{mg} / \mathrm{kg})\left(1 \times 10^{6} \text { cells } /\right. \\
\text { mouse } / \mathrm{ml})\end{array}$ & $\begin{array}{c}\text { MESP + DAL } \\
(300 \mathrm{mg} / \mathrm{kg})\left(1 \times 10^{6} \text { cells } /\right. \\
\text { mouse } / \mathrm{ml})\end{array}$ & $\begin{array}{c}\text { Standard + DAL (20 mg / } \\
\text { kg) }\left(1 \times 10^{6} \text { cells / mouse / }\right. \\
\text { ml }) \\
\end{array}$ \\
\hline Body weight (g) & $25.00 \pm 1.15$ & $22.17 \pm 0.945^{*}$ & $18.50 \pm 0.76^{* * *}$ & $15.67 \pm 0.88 * * *$ \\
\hline PCV $(\mathrm{ml})$ & $1.283 \pm 0.10$ & $1.13 \pm 0.16^{*}$ & $0.75 \pm 0.061 * *$ & $0.45 \pm 0.076 * * *$ \\
\hline Tumor volume $(\mathrm{ml})$ & $4.78 \pm 0.288$ & $3.76 \pm 0.189 * * *$ & $3.58 \pm 0.166^{* * *}$ & $2.267 \pm 0.189 * * *$ \\
\hline $\begin{array}{l}\text { Viable tumor count } \\
\left(10^{6} \text { cells } / \mathrm{ml}\right)\end{array}$ & $9.28 \pm 0.308$ & $4.733 \pm 0.248^{* * *}$ & $3.66 \pm 0.215^{* * *}$ & $2.86 \pm 0.166^{* * *}$ \\
\hline $\begin{array}{l}\text { Non viable tumor } \\
\text { count }\left(10^{6} \text { cells } / \mathrm{ml}\right)\end{array}$ & $0.61 \pm 0.15$ & $3.5 \pm 0.76^{*}$ & $4.5 \pm 0.76^{* * *}$ & $6.3 \pm 0.71 * * *$ \\
\hline
\end{tabular}

Values are mean \pm SEM, number of mice in each group $(n=6)$. Experimental groups were compared with DAL control. (Weight of normal mice $(20 \pm 5$ g) $* \mathrm{P}>0.05, * * \mathrm{P}<0.05, * * * \mathrm{P}<0.01$

Table 2: Effect of Methanolic Extract of Solanum pubescens on Mean Survival Time and \% Increase in Life Span on DAL Bearing Mice

\begin{tabular}{|c|c|c|}
\hline Experiment & Mean Survival Time (Days) Mean \pm SEM & \% increase in life span (\% ILS) \\
\hline DAL Control $\left(1 \times 10^{6}\right.$ cells $/$ mouse $\left./ \mathrm{ml}\right)$ & $22.17 \pm 0.10$ & - \\
\hline MESP + DAL $(200 \mathrm{mg} / \mathrm{kg})\left(1 \times 10^{6}\right.$ cells $/$ mouse $\left./ \mathrm{ml}\right)$ & $29.83 \pm 1.4^{*}$ & $34.55 \%$ \\
\hline MESP + DAL $(300 \mathrm{mg} / \mathrm{kg})\left(1 \times 10^{6}\right.$ cells $/$ mouse $\left./ \mathrm{ml}\right)$ & $37.50 \pm 1.47 * *$ & $69.14 \%$ \\
\hline Standard + DAL $(20 \mathrm{mg} / \mathrm{kg})\left(1 \times 10^{6} \mathrm{cells} / \mathrm{mouse} / \mathrm{ml}\right)$ & $42.67 \pm 1.909 * *$ & $92.46 \%$ \\
\hline
\end{tabular}

Values are mean \pm SEM, number of mice in each group $(\mathrm{n}=6)$. Experimental groups were compared with DAL control. (Weight of normal mice $(20 \pm 5$ g) $* \mathrm{P}>0.05, * * \mathrm{P}<0.05, * * * \mathrm{P}<0.01$

Table 3: Effect of Methanolic Extract of Solanum pubescens on Hematological Parameters of DAL Treated Mice

\begin{tabular}{|c|c|c|c|c|}
\hline Parameters & $\begin{array}{l}\text { DAL Control }\left(1 \times 10^{6}\right. \\
\text { cells / mouse / ml })\end{array}$ & $\begin{array}{c}\text { MESP + DAL } \\
(200 \mathrm{mg} / \mathrm{kg})\left(1 \times 10^{6}\right. \\
\text { cells } / \text { mouse } / \mathrm{ml}) \\
\end{array}$ & $\begin{array}{c}\text { MESP + DAL } \\
(300 \mathrm{mg} / \mathrm{kg}) \\
\left(1 \times 10^{6} \text { cells } / \text { mouse } / \mathrm{ml}\right)\end{array}$ & $\begin{array}{c}\text { Standard + DAL }(20 \mathrm{mg} \\
/ \mathrm{kg})\left(1 \times 10^{6} \text { cells } /\right. \\
\text { mouse } / \mathrm{ml})\end{array}$ \\
\hline Total RBC $\left(\right.$ cells $\left./ \mathrm{ml} \times 10^{6}\right)$ & $5.83 \pm 0.94$ & $7.83 \pm 0.65 *$ & $8.33 \pm 0.88^{*}$ & $10.50 \pm 0.42 * * *$ \\
\hline Total WBC $\left(\right.$ cells $\left./ \mathrm{ml} \times 10^{6}\right)$ & $14.67 \pm 1.2$ & $12.33 \pm 0.71 *$ & $11.17 \pm 0.47 * *$ & $10.17 \pm 0.600^{* * *}$ \\
\hline Hemoglobin $(\mathrm{g} \%)$ & $12.33 \pm 0.88$ & $14.67 \pm 1.11^{*}$ & $18.17 \pm 1.24 * * *$ & $16.17 \pm 1.515^{* *}$ \\
\hline Platelet count (Lakhs / cumm) & $1.83 \pm 0.40$ & $6.167 \pm 1.10 * * *$ & $6.167 \pm 1.04 * * *$ & $4.66 \pm 0.66^{* * *}$ \\
\hline
\end{tabular}

Values are mean \pm SEM, number of mice in each group $(n=6)$. Experimental groups were compared with DAL control. (Weight of normal mice $(20 \pm 5$ g) $* \mathrm{P}>0.05, * * \mathrm{P}<0.05, * * * \mathrm{P}<0.01$

Table 4: Effect of Methanolic Extract of Solanum pubescens on Biochemical Parameters of DAL Treated Mice

\begin{tabular}{|c|c|c|c|c|}
\hline Parameters & $\begin{array}{l}\text { DAL Control }\left(1 \times 10^{6}\right. \\
\text { cells / mouse } / \mathrm{ml})\end{array}$ & $\begin{array}{c}\text { MESP + DAL } \\
(200 \mathrm{mg} / \mathrm{kg})\left(1 \times 10^{6}\right. \\
\text { cells / mouse / ml })\end{array}$ & $\begin{array}{c}\text { MESP + DAL } \\
(300 \mathrm{mg} / \mathrm{kg})\left(1 \times 10^{6} \text { cells } /\right. \\
\text { mouse } / \mathrm{ml})\end{array}$ & $\begin{array}{c}\text { Standard + DAL }(20 \mathrm{mg} / \\
\mathrm{kg})\left(1 \times 10^{6} \text { cells } / \text { mouse } /\right. \\
\mathrm{ml})\end{array}$ \\
\hline $\begin{array}{c}\text { Total } \\
\text { Cholesterol } \\
\end{array}$ & $145.8 \pm 2.75$ & $113.0 \pm 1.183 * * *$ & $116.3 \pm 1.352 * * *$ & $119.3 \pm 1.229^{* * *}$ \\
\hline Triglycerides & $217.0 \pm 2.06$ & $206.5 \pm 2.705 * *$ & $196.3 \pm 2.404 * * *$ & $150.2 \pm 1.869 * * *$ \\
\hline AST & $89.83 \pm 1.64$ & $70.00 \pm 1.36^{* * *}$ & $66.33 \pm 1.745^{* * *}$ & $55.67 \pm 1.764 * * *$ \\
\hline $\mathrm{ALT}$ & $56.17 \pm 1.42$ & $57.17 \pm 1.68 * * *$ & $47.33 \pm 0.66^{* * *}$ & $42.50 \pm 0.957 * * *$ \\
\hline ALP & $242.5 \pm 2.680$ & $178.3 \pm 2.108^{* * *}$ & $172.0 \pm 1.78 * * *$ & $165.8 \pm 1.721 * * *$ \\
\hline
\end{tabular}

Values are mean \pm SEM, number of mice in each group $(\mathrm{n}=6)$. Experimental groups were compared with DAL control. (Weight of normal mice $(20 \pm 5$ g) $* \mathrm{P}<0.05, * * \mathrm{P}<0.01, * * * \mathrm{P}<0.001$

\section{RESULTS}

The phytochemical screening of plant extracts showed the presence of alkaloids, tannins like phenolic compounds, flavanoids and steroids. Hence the potent anticancer activity of MESP may be due to any of these phytoconstituents. The effect of MESP on the survival of DAL tumor bearing mice is shown in Table 2. The effects of MESP (200 and $300 \mathrm{mgkg}-$ 1 ) at different doses on tumor volume, viable and non viable cell count, survival time and \%ILS were shown in Table 1 and 2. Administration of MESP reduces the tumor volume, packed cell volume and viable tumor cell count in a dose dependent manner when compared to DAL control mice. In DAL control mice the mean survival time was $22.17 \pm 2.10$ days; whereas, it was significantly increased mean survival time $(29.83 \pm 1.4,37.50 \pm 1.47)$ with different doses $(200$ and 300 mgkg-1) of MESP and standard drug (42.67 \pm 1.90$)$ respectively. As shown in Table 3, the hemoglobin content in the DAL control mice (12.33 g \%) was significantly 
decreased when compared with normal mice (13.50 g \%) MESP at the dose of (200 and $300 \mathrm{mgkg}-1)$ the hemoglobin content in DAL treated mice were increased to $14.67 \pm 1.11$ and $18.17 \pm 1.24 \mathrm{~g} \%$ moderates changes in the RBC count for also observed in extract treated mice. The total WBC counts were significantly higher in DAL treated mice when compared with normal mice. Figure 1 shows the Histopathological observation of liver section of control and experimental animals. Control animals showed normal lobular architecture. The portal tract shows normal morphology without any inflammation or fibrosis. The

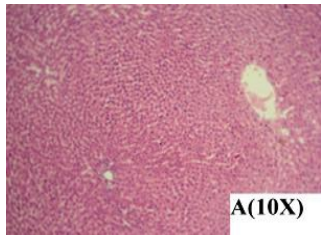

(a) Normal control

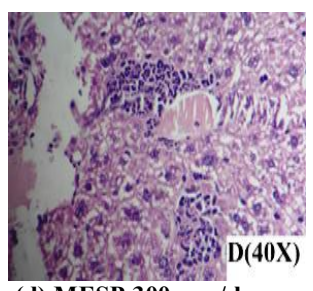

(d) MESP $300 \mathrm{mg} / \mathrm{kg}$

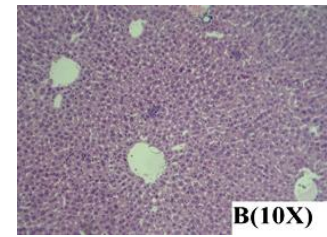

(b) DAL Control

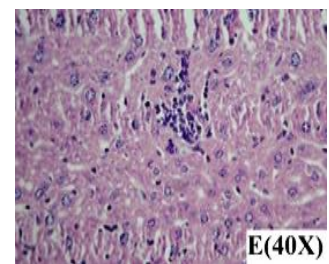

(e) 5-Furouracil hepatocytes are unremarkable. The central vein and the sinusoids are normal. There is no lobular inflammation, granuloma or fibrosis; whereas DLA induced mice showed few foci of atypical cells with mitotic figures seen in the liver parenchyma and perivenular region. The hepatocytes show some degenerative changes. However mice treated with MESP showed almost normal lobular architecture. Mice treated with 5-fluorouracil shows no inflammation or fibrosis. The liver parenchyma show many foci of collection of cells among the hepatocytes.

Figure 1: Photomicrographs of Rat Liver Stained by Haematoxylin and Eosin of Normal Control (a), DAL Treated Control (b), Extracted Treated Group (c, d) and the Standard Drug 5- flurouracil (e)

\section{DISCUSSION}

The present study was carried out by to evaluate the effect of MESP and DAL bearing mice. The MESP showed anti tumor activity against the tumor. The reliable criteria for judging the value of any anti cancer drug are the prolongation of life span of animals ${ }^{16}$. A reduction in the number of ascetic tumor cells may indicate either an effect of MESP on peritoneal macrophages or other components of the immune system ${ }^{17}$, therefore increasing their capacity of killing the tumor cells, or a direct effect on the tumor cell growth. MESP is inhibiting significantly the tumor volume, viable cell count and enhancement in survival time of DAL bearing mice and there by acts as anti-neoplastic agent. Myelosupression is a frequent and major complication of cancer chemotherapy. MESP treated and subsequent tumor inhibition resulted in appreciable improvements in hemoglobin content, RBC and WBC counts (Table 3). These observations assume great significance, as anemia is common complication in cancer and the situation aggravates further during chemotherapy since a majority of antineoplastic agents exert suppressive effects on erythropoiesis ${ }^{18,19}$ and thereby limiting the use of these drugs. The improvement in the hematological profile of the tumor bearing mice following the treatment with the extract could be due to the action of the different phytoconstituents present in the extracts. Histopathological assessment of different liver segments of the control and experimental animals by light microscope has been examined. Liver section of cell line (DLA) induced mice showed structural alteration in nucleus. The major alteration was damaged central vein, degenerative changes in hepatocytes; Atypical cells seen in liver parenchyma and perivenular region. This damage is partially reversed by the Solanum pubescens leaves extract treatment.

\section{CONCLUSION}

The result of the present investigation is encouraging and explores the potent anticancer activity of Solanum pubescens, most likely because of its direct cytotoxic effect. A decrease in cancer cell count provides confirmatory evidence for protection against DAL, with increased life span observed in extract treated mice. Haematological parameters and biochemical parameters also provide evidence of the protective effect of Solanum pubescens against DAL. The anticancer properties of the extracts may be due to the presence of flavanoids, alkaloids and terpenoids. The present findings may pave the way for the bioactivity guided fractionation and isolation of novel lead compounds in Solanum pubescens for anticancer chemotherapy. This will be useful for the design and synthesis of potent anticancer components, hence beneficial for the patients.

\section{ACKNOWLEDGEMENTS}

The authors would like to acknowledge chairmen of T.R.R.C.P. Hyderabad, India for providing necessary facilities to carry out the study.

\section{REFERENCES}

1. Kanchana A, Balakrishna M. Anti-cancer effect of saponins isolated from Solanum trilobatum leaf extract and induction of apoptosis in human larynx cancer cell lines. International Journal of Pharmacy and Pharmaceutical Sciences 2011; 3(4): 356-364.

2. Kleinsmith LJ. Principles of Cancer Biology, $4^{\text {th }}$ ed. Pearson Benjamin Cummings in San Francisco; 2007. p. 312.

3. Christina AJ, Joseph DG, Packialakshmi M, Kothai R, Robert SJ, Chidambaranathan N, Ramasamy M. Anticarcinogenic activity of Withania somnifera Dunal against Dalton's ascitic lymphoma, J. Ethnopharmacol 2004; 93: 359-361. http://dx.doi.org/10.1016/j.jep.200 4.04.004 PMid: 15234777

4. Unnikrishnan MC, Kuttan R. Tumour reducing and anticarcinogenic activity of selected spices. Cancer Letters 1990; 51: 85-89. http://dx. doi.org/10.1016/0304-3835(90)90235-P 
5. Babu TD, Kuttan G, Padikkala J. Cytotoxic and anti-tumour properties of certain taxa of Umbelliferae with special reference to Centella asiatica (L.) Urban. J. Ethnopharmacol 1995; 48: 53-57. http://dx.doi .org/10.1016/0378-8741(95)01284-K

6. K Hemamalini, P Ashok, G Sunny, S Kumar Reddy, G Ganesh, K Santoshini, K Rashmita, P Priyanka, Y Jayasri, T Vishwanath, Uma Vasireddy. Gastroprotective Activity of Gymnosporia emerginata, Solanum pubescence and Anogessius accuminata Leaf Extract against Ethanol-induced Gastric mucosal injury in Rats; International Journal of Pharmaceutical and Biomedical Research 2011; 2(1): 38-42.

7. Hemamalini K, Uma Vasireddy, Vamshi G, Harinath K, Vishnu Vardhan E, Nagarjun Goud A, Raghu H and Sharath Goud T. In-vitro Anthelmintic Activity of Solanum pubescens and Gymnosporia emerginata Leave; International Journal of Pharma and Bio Sciences $2011 ; 2(3)$.

8. Hemamalini K, Umavasi Reddy, Viswaja M, Nagarjuni Y, Sandhya Rani V and Vinitha G. In-vitro Screening of Anti Lice Activity of Three different Leaves; International Journal of Phytopharmacy Research 2011;2(2): 54-57.

9. Kumari GNK, Rao LJM, Rao NSP. Flavonol 3-O-Methyl Ethers from Solanum pubescens; Journal of Natural Products 1985; 48(1): 149-150. (6 ref.)

10. Krishna Kumari GN, Rao LJM, Rao KVR, Rao NSP, Kaneko K, Mitsuhashi H. Solanopubamine, a steroidal alkaloid from Solanum pubescens; Phytochemistry 1985; 24(6): 1369-1371. http://dx. doi.org/10.1016/S0031-9422(00)81136-X
11. Madhava Chetty K, Sivaji K and Tulasi Rao K. Flowering plants of Chittor District, Andhra Pradesh, India; 2008. p. 330-333.

12. Trease GE, Evans WC. Pharmacognosy. London: $13^{\text {th }}$ ed. Bailliere Tindall; 1989. p. 176-180

13. Pandey Govind, Madhuri S. Medicinal plants: better remedy for neoplasm. Indian Drugs 2006; 43: 869-874.

14. D Armour FE, FR Blad and DA Belden. Manual for laboratory words in physiology. The University of chicago press, Chicago iiinois $3^{\text {rd }} \mathrm{Ed}$; 1965. p. 4-6.

15. Wintrobe HM, GR Lee, DR boggs, Tc Bithel, JW Ethens and J Foerester: Clinical hematology, Lea and Febiger, Philadelphia, PA $5^{\text {th }}$ ed; 1961. p. 326

16. Prasd SB and A Giri. Anti tumor Effect of cisplatin against murine ascites DAL indian J. Exp. Biol 1994; 32: 155-162.

17. Kleeb SR, JG Xavier, R Frussa Filho and MLZ Dagli. Effect of Haloperidolon the Ehrlich tumor in mice. Lifesci 1997; 60: 69-74.

18. Price VE, RE Greenfield, WR Sterling and RC Maecardle. Studies on the anemia on the tumor bearing animals. J. Nat. can. Ins 1959; 22: 877885 .

19. Hogland HC. Hematological complications of Cancer Chemotherapy semi Oncol 1982; 9: 95-102.

\section{Cite this article as:}

K. hemamalini and Anurag bhargav. Evaluation of phytochemical and pharmacological activity of methanolic extract of Solanum pubescens. Int. Res. J. Pharm. 2013; 4(8):138-142 http://dx.doi.org/10.7897/2230$\underline{8407.04825}$ 